progressively enlarged, and stage by stage the tunnel was lined with cast-iron segments each weighing about a ton, placed in position by a special erecting machine. All segments were machined at the joints and watertightness was ensured by the use of lead caulking. The $4 \frac{1}{2}$ in. space between the back of the circular lining and the rock was then filled in with stone and a grout of cement and sand. Later on, the internal spaces of the segment were filled with concrete and finally finished with creamcoloured gypsum plaster sprayed with a transparent polish.

The roadway of reinforced concrete is built on a line a little below the horizontal diameter of the tunnel and is supported on two longitudinal reinforced concrete walls $21 \mathrm{ft}$. apart. These walls divide the lower portion of the tunnel into three sections, the centre one of which may perhaps at some future time be used for single-deck tramcars, and two side passages, approximately triangular in section, which will be used for the supply of fresh air. The air will find its way into the tunnel through longitudinal ducts on either side of the roadway at the level of the kerb. Provision is also made for electric cables, water mains and drainage pipes.

The ventilation system was designed after fullscale experiments on a length of $1,000 \mathrm{ft}$. of finished tunnel using full-sized fans. These experiments were supervised by physiologists and ventilation experts, and they were also directed to ascertain which system would give the best results in the event of a serious petrol fire. As a basis, a traffic flow of 3,000,000 vehicles a year was assumed, and the plant as installed will ensure that, under normal conditions, the proportion of carbon monoxide will not exceed $2 \frac{1}{2}$ parts in 10,000 parts of air, or 4 parts in 10,000 under extreme peak-load conditions. There are six ventilation buildings, three on each side of the river, with supply and exhaust fans, the whole plant including 30 fans with a total capacity of $10,000,000 \mathrm{cub}$. ft. of air per minute, each section of the plant being duplicated. Each ventilation building consists of a steel-framed structure with a central tower. In each case, fresh air will be drawn through intakes in the roof of the building by the supply fans and discharged into the air ducts, while the foul air will be drawn by the exhaust fans from the upper part of the tunnel and discharged up the central tower. All the fans are electrically driven and are remotely-controlled from the ventilation building at George's Dock, Liverpool, which will house the administration offices. The many other interesting features of this great undertaking include the pumping plant for dealing with water which may find its way into the tunnel, a system of lighting which does away with the necessity of cars switching on their head or side lights, fire and telephone stations and signals for instructing drivers to stop their engines. The cost of the whole scheme, including purchase of the land, has been about $£ 7,000,000$, towards which the Government made a grant of $£ 2,500,000$ from the Road Fund. Loans have been raised by the Corporations of Liverpool and Birkenhead which will be paid back out of the tolls and the rates. A fully illustrated account of this important work was given in Engineering of January 19, February 16 and March 16.

\title{
International Council of Scientific Unions Meeting at Brussels
}

1 HE International Council of Scientific Unions (formerly the International Research Council) held its first triennial meeting, since its new statutes were adopted, on July 8-13 at Brussels. The general assembly of delegates met at the Palais des Académies, Brussels, and elected Dr. N. E. Nörlund, director of the Geodetic Institute, and Rector of the University of Copenhagen, president for the period 1934-37; General J. F. Bourgeois, of the Academy of Sciences, Paris, and Marchese Marconi, president of the National Research Council of Italy, were elected vicepresidents. Dr. Pelseneer and Dr. Went remain members of the executive committee, and Sir Henry Lyons the general secretary.

At this meeting for the first time, the International Unions of Astronomy, Geodesy and Geophysics, Chemistry, Scientific Radio, Physics, Geography and the Biological Sciences, attended as members of the Council, and communicated very interesting accounts of their activities in their respective scientific fields of work during the past three years.

For the first time also, addresses were given on scientific matters of general interest, and these included, on this occasion, one by Dr. D. la Cour on the International Polar Year, 1932-33, its aims, methods and some preliminary results; another by General G. Perrier, on recent international determinations of longitude; while Dr. E. P. Hubble spoke on the exploration of space, and Prof. H. R. Kruyt on electricity and hydration with colloids.

The International Committee on the Relationship between Solar and Terrestrial Phenomena was reappointed, and another on instruments and methods met to arrange its future procedure.

The following motion, put forward by the Royal Academy of Sciences, Amsterdam, was unanimously adopted by the General Assembly:

"The International Council of Scientific Unions, being aware of the fact that the present economic and political difficulties have brought humanity face to face with a number of the most complicated and dangerous problems and threaten to erect a system of barriers between various nations, expresses its deep faith that ultimately a way will be found leading towards a more harmonious economic structure, and wishes to stress the importance of maintaining by all means international co-operation in the 
domain of science under whatever circumstances may present themselves.

"As laid down in its Statutes, the Council recognises the relations between pure and applied science. There is no doubt that both governments and industrial groups will in an ever increasing degree call upon scientists for elucidation of the manifold complexities and problems which human life and human relationship are presenting - problems, the most important of which perhaps are those of finding food, space in which to live and employment for the various peoples spread over the earth. If at the present moment an international organisation devoted to the solutions of these problems is still beyond our vision, and organisation constructed according to national systems must provisionally be strengthened for fear of losing hold of economic possibilities, it can be foreseen that the scientists of every country will be drawn more and more into these spheres of national organisation. The Council expresses its confidence that scientists, while giving their aid in meeting the needs of their own nations, will never lose sight of the international character of science as a whole, and will ever continue to keep in working order and to develop the connections necessary for international co-operation, even if severe shocks unhappily might come to threaten economic and political relations.

"In professing its faith in the possibility and the necessity of peace between the world's peoples, the Council points out that the "brotherhood of scientists" can be an important factor towards the establishment of a desire for mutual understanding and helpfulness in order to overcome the dangers involved in a too exclusive nationalism.

"The Council therefore, in emphasising the significance of science, both pure and applied, as a common treasure for all humanity, which can only be realised through a free-spirited co-operation of the most diverse elements, is of opinion that scientists of the whole world have a task of working for this understanding, and urges all allied organisations to give constant attention to this task."

The General Assembly accepted unanimously an invitation from the Royal Society to meet in London in 1937.

\section{Obituary}

\section{Mme. CurIe}

$\mathrm{M}$ ME. CURIE, whose death occurred on July 4 after a brief illness, held an outstanding position in science, for she had long been regarded as the foremost woman investigator of our age. Although her greatest scientific work, the discovery and isolation of radium, was done nearly thirty years ago, yet, as professor in the Sorbonne and director of the Radium Institute in Paris, Mme. Curie until the time of her death was actively engaged in researches on the physical and chemical properties of the radioactive bodies. At the same time, she was also director of a vigorous school of research which attracted investigators from many countries. During the last few years, she was engaged in preparing preparations of actinium much stronger than had previously been available, for the purpose of examining the fine structure of the $\alpha$-ray groups emitted by the products of this element. With the help of her colleague, Dr. Rosenblum, and the use of the large Paris electro-magnet, many new results of importance were obtained.

Marie Sklodowska was born at Warsaw on November 7, 1867, and received her early education in that city. Interested in science, she resolved, notwithstanding financial difficulties, to go to Paris to perfect her scientific training, and took lectures and examinations in the Sorbonne. In 1895 she married Pierre Curie, a young physicist in Paris who was making those highly original and fundamental contributions to magnetism and crystallography so well known to every student to-day. The young couple joined forces in their scientific work, which was carried out initially under difficult conditions, for laboratory arrangements were poor, and both had to undertake much teaching to gain a livelihood.

The turning point of the scientific career of Mme. Curie came as a consequence of the fundamental discovery of radioactivity by Henri Becquerel in Paris in 1896. He showed that the element uranium spontaneously emitted new types of penetrating radiation which darkened a photographic plate and discharged electrified bodies. This new discovery attracted the attention of Mme. Curie and, using the electric method as a means of quantitative analysis, she showed that the radioactivity of uranium was an atomic property. She also observed that the mineral pitchblende, from which uranium was separated, showed four to five times the activity due to the uranium alone. Since the activity of uranium was due to the atoms alone, this observation could only be explained by the presence of a new element or elements in the pitchblende much more active than uranium.

Boldly relying on this hypothesis, Mme. Curie made a systematic chemical analysis of pitchblende, using the electric method as a means of qualitative and quantitative analysis of the activity of her preparations. The first active element observed by these methods had properties allied to bismuth and was called polonium after her native country. She later discovered the presence of another element, happily named radium, which was similar in chemical properties to barium. We now know that radium is one of the long series of products of the radioactive transformation of uranium and exists in uranium minerals in about 1 part in 3 millions compared with uranium, and weight for weight shows an activity many million times that of uranium. The paper announcing this discovery was published in the Comptes rendus of 1898 under the names of M. and Mme. Curie and G. Bemont.

While at this stage, M. and Mme. Curie did all their scientific work together, it is natural to assume that Mme. Curie, as the chemist of the combination, was mainly responsible for the chemical work involved. She alone was responsible for the large-scale chemical work required to separate radium from radioactive residues in sufficient quantity to purify it and obtain its 